\title{
NEW PARADIGMS OF RURAL DEVELOPMENT
}

(Received: 6.1.2011)

\author{
By \\ T.M. K.Abdelhakim
}

Mediterranean Agronomic Institute ,3191 Route de Mende,34093 Montpellier, France

\begin{abstract}
The rural landscape has undergone a number of profound changes leading to a need to redefine the concept of "rurality. In order to take account of these transformations, rural development must take the form of local development based on the optimisation of local resources and the mobilisation of all parties, both public and private. The approaches to rural development are rooted in the major theories of development and it is the renewal of the latter which has given rise to the new paradigms of rural development, namely governance, decentralisation, multi-functionality and territory.
\end{abstract}

Keywords: decentralisation, governance, multi-functionality, rural development, rurality theory of development, territory.

\section{INTRODUCTION}

During the past two decades, rural development has gradually come to occupy an increasingly important place. This is true in both national development strategies and the orientations of the major international organisations operating in the field of development. Rural development has thus become the second pillar of the European Union's Common Agricultural Policy (CAP), thereby bearing witness to the importance accorded to the issue of rural areas. Furthermore, several countries in the southern Mediterranean basin have adopted a specific strategy of rural development, for example the Rural Renewal Policy in Algeria (PRR) and the Rural Development Strategy in Morocco.

This distinction between agricultural development and rural development is reflected in a number of profound demographic and economic changes. This in turn has necessitated the adoption of new approaches and new paradigms enabling the question of rural development to be examined in a more suitable and efficient manner.

The aim of this analysis was to present the new paradigms of rural development and understand their theoretical origins. However, the definition of rurality will be first revised before presenting the sources of renewal of the theories of development and finally identifying the paradigms of rural development.

\section{Revising the definition of rurality}

Easily identified in the past through the predominance of agriculture, the concept of rurality has become more difficult to define due to a widespread change in lifestyles and consumption practices. However, the fact that agriculture is no longer the sole or predominant activity observed in rural areas both within Europe and on the southern shores of the Mediterranean has complicated things.

Despite the fact that agriculture still plays a central role in the rural areas of countries in the southern and eastern Mediterranean basin ${ }^{1}$, we nevertheless note a fall in the relative importance of agriculture both in demographic and economic terms. While the total number of agricultural workers has increased in the countries of the southern and eastern Mediterranean basin, their relative weight in population as a whole has fallen (Mediterra, 2008, page 77). In 1970, in all these countries with the exception of Lebanon and Libya, the proportion of agricultural workers totalled more than $50 \%$ of the total working population whereas in 2004, this figure only reached 30\% in Morocco and Turkey. With the exception of Syria, the share of agriculture in the GDP of all the southern and eastern Mediterranean countries has fallen below $20 \%$ while the average proportion fell from 15 to $12 \%$ of GDP between 1999 and 2005 (Mediterra, 2008 page 78). Finally, the rate of unemployment is systematically higher in rural areas than in urban zones.

In the countries of the EU, the definition of rural has been reformulated several times to reflect

\footnotetext{
${ }^{1}$ Morocco, Algeria, Tunisia, Libya, Egypt, Lebanon, Syria, Jordan, Turkey.
} 
the profound democratic and economic transformations that have taken place. As a result of the agricultural modernisation policies introduced in the 1960s within the framework of the common agricultural policy, agricultural productivity has continued to increase. This was accompanied with a decline of the relative weight of agriculture in terms of both the population in general and the working population in particular. Between 2000 and 2009, employment in the agricultural sector fell by $25 \%$ within the 27 -states of the EU. A fall of $17 \%$ was observed in the group of $15 \mathrm{EU}$ states before expansion while a fall of $31 \%$ could be seen in the 12 member states which have joined the union since 2004 (Eurostat News Releases on the Internet: http://ec.europa.eu/eurostat, May 2010).

In 2006, agricultural employment represented $6 \%$ of the total employment in the EU with levels ranging from $1 \%$ in the United Kingdom to $30 \%$ in Romania. In 2004 in countries such as France, Spain and Italy, agricultural workers accounted for only $3 \%, 6 \%$ and $4 \%$, respectively of the total active population (Mediterra 2008). Despite this fall, the rural population of the 27-states of the EU represents $56 \%$ of the total population, indicating a change in the composition of the populations living in rural areas where agricultural households are still the majority.

This marked change in the demographic and economic situation has given rise to a need to revise the definition of "rural" insofar as we can no longer refer to an exclusive or predominant agricultural activity. The EU has adopted a methodology ${ }^{2}$, developed by the OECD, which takes account of a continuum from urban to rural and meanwhile considers the existence of urban centres in rural territories (Rural Development

\footnotetext{
2 The basic criterion is that of population density. "Rural" relates to the parish (basic local unit) with a density of fewer than 150 inhabitants/ $\mathrm{km}^{2}$. This is followed by a classification involving three categories of regions (NUTS): predominantly rural regions (if more than $50 \%$ of the population lives in rural parishes); intermediate regions (if between 15 and 50\% of the population lives in rural parishes) and predominantly urban regions (if less than $15 \%$ of the population lives in rural parishes). An urban centre with a population of more than 200,000 inhabitants representing not less than $25 \%$ of the population in a predominantly rural region, will be classified as an intermediate region. An urban centre with a population of more than 500,000 inhabitants representing not less than $25 \%$ of the population in an intermediate region will be classified as a predominantly urban region (Rural development in the EU, report 2009).
}

Report, EU, 2009). Moreover, the definition of "rural" must incorporate the new functions of these areas, i.e. residential and environmental functions.

This necessary revision of the definition of "rural" involves several changes in the approaches to rural development. The first is to avoid restricting rural development to agricultural development. Rural development encapsulates agricultural development as well as the development of all other sectors of economic activity. Consequently, rural development is founded on the optimisation of the local resources of each territory. Identifying and optimising local resources is an endogenous dynamic process which necessarily requires involvement of all local actors, both public and private.

Thus, approaches to rural development must take account of these three elements, i.e. the fact that rural development is a multi-sector and local phenomenon that is driven by local operators.

\section{Approaches to rural development and their theoretical origins}

What are the roots of the approaches of rural development? We often think of rural development as a sum of different practices and polices. In fact, the approaches of rural development are rooted in the major theories of development. Historical analysis of the development of these approaches clearly shows that they change in step with the evolution of the theories of development and are directly influenced by them.

The different approaches of rural development can be divided into two categories: descriptive approaches and explanatory approaches.

The first category is that of the historical approaches dating back to the period 1950-1970. These approaches that are founded on normative theories and the concept of modernisation focus on the modernisation of agriculture, agrarian reforms, the transfer of technologies and extension. The strong technical aspect is combined with an economic vision turned towards an increase in the production and productivity of agricultural labour. These approaches of development, which link "rural" to "agricultural", are characterised by strong state intervention and a top-down approach.

The theoretical roots of these approaches can be found in the three major theories of development of the period in question. These are ROSTOW's theory of the stages of economic growth, the dualist theory put forward by A. LEWIS and, in part, the structural school. In 
ROSTOW's theory of the stages of economic growth, development rhymes with the modernisation of traditional societies through the dissemination of technical progress.

According to the dualist theory, the duality between the traditional sector and the modern sector which characterises the situation of underdevelopment is at the root of the development process (Lewis, 1963). The hypothesis here is that the traditional sector enjoys surplus labour and that the transfer of this labour towards the modern sector enables the latter to keep salaries low and thus increase profits, thereby leading to an accumulation of capital which forms the basis of economic development.

The contribution of the structural school of thought can primarily be seen in state intervention. According to the structuralist theories, the structural particularities of the economies of underdeveloped countries do not enable market mechanisms to function correctly. Hence, there was a need for a strong state intervention to guide the process of development.

From the end of the 1970s, the economic crisis resulting from the failure of the development models in the countries of the South and the far-reaching consequences of the profound changes introduced in the agricultural sector in the countries of the North cast doubts over these normative approaches. Hence, the technoeconomic models were designed and imposed far from the reality in the field. Systemic analysis became a favoured tool in defining explanatory approaches to reality and attempting to understand the socio-economic reasoning of farmers as well as their strategies. The "farming system" approach represented an important contribution in this context. Primarily technical, the analysis of production systems incorporated a socio-economic element, as a production system is always the product of an interaction between an ecosystem and a social training at a certain moment in time.

In the same perspective, at the beginning of the 1980s, the local development approach became the main approach to rural development. Introducing a bottom-up rationale, local development represented a break with the topdown and interventionist approaches. The mobilisation of the local populations replaced more or less directive extension while local strategies were introduced to replace a single and unique strategy applicable to the entire national territory. The process of demarcating the "local" level nevertheless encountered certain difficulties. It raised numerous questions concerning the relevance of the administrative divisions, the physical and demographic size of the area concerned by the local development, and the overlapping of different levels of intervention. Despite these criticisms, the approach of local development continued to progress with the experimentation of new terms and conditions for actions.

The acknowledged failure of the structural adjustment policies, the acceleration of the globalisation process and the issue of the environment represent major transformations and new issues have come to the fore since the 1990s. This context was conducive to the renewal of the theories of development.

\section{The sources of the renewal of the theories of development}

Five sources contributed to the renewal of the theories of development:

- The neo-structuralist school of thought

- The theory of endogenous growth

- Institutional economics

- Territorial economics

- SEN's theory of capabilities.

\subsection{The neo-structuralist school of thought and the theory of endogenous growth}

The neo-structuralist analysis emphasises the need to look beyond the false "state/market" dilemma. It stresses the complementary relation and pulling-in effect between public investment and private investment and introduces human capital as a factor of economic efficiency (Ehrhart, 2004). Similarly, the theory of endogenous growth considers innovation, the role of the state and human capital as factors of economic growth. Going beyond liberal analyses which reduce the functions of the state to that of a guardian of the law, it is acknowledged that public investments in infrastructures and in spending linked to human capital (education and health) are essential and create an environment conducive to private investment.

\subsection{Institutional economics}

Interest in the institutions and their role in the development process represented a major contribution of institutional economics to the theories of development. Contrary to standard economic theory, which excluded the institutions from its scope of interest, institutional economics sees the action and choices of individuals as being mediatised by the institutions representing collective action and the site in which the rules are produced. Institutions are defined in several ways: they are "habitual procedures and established thoughts, or they are a normative system with the function of regulating interactions" (Thorstein, 1995). The difference between institutions and 
organisations is explained by North(1997), who claims that "institutions are the rules of the game of a society or, more formally, are the humanly devised constrains that structure human interaction". They are composed of formal rules (statute law, common law, regulations), informal constraints (conventions, norms of behaviour and self-imposed codes of conduct), and the enforcement characteristics of both. Organisations are the players: groups of individuals bound by a common purpose to achieve objectives. They include political bodies (political parties, the senate, a city council, a regulatory agency) economics bodies (firms, trade, unions, family farms, cooperatives) social bodies (school, colleges, vocational training centres)" (North, 1997).

Coase, 1988, Williamson, 2000 and North, 2005 are just some of the proponents of the new institutional economics which produced new concepts and theories aimed at improving our understanding of the relationship between institutions and development, including the theory of transaction costs. This theory states that economic activity is based on exchanges which give rise to transaction costs. These costs are generated by asymmetric and incomplete information as well as by uncertainty with regard to the behaviour of economic operators. Institutions are a means of coordinating economic activities to minimise transaction costs, thereby contributing to increasing economic efficiency. Pursuing this line of thought, D. North links economic change to institutional change when he explains that to understand economic change, it is necessary to look beyond the economic dimension in its strict sense by incorporating demography (quantity and quality of human resources), the stock of knowledge and the institutional framework (North, 2005). Building an economic theory of non-market or non-commercial institutions helps understand how individuals can use non-market institutions to improve the level of collective well-being when this is impossible via the market.

The contribution of institutionalism to the analysis and understanding of the processes of development is fundamental (Bates, 1997). First, by explaining how economic development depends on a favourable institutional environment and by demonstrating that it is neither the state (completely centralised institutions) nor the market (completely decentralised institutions) which is the best means of providing goods and services. New institutional economics offers an alternative with an approach based on collective action and civic commitment (Toye, 1997).

\subsection{Territorial economics}

Developed gradually over the past 20 years, the theoretical corpus referred to as "territorial economics" marks a new approach to the relationship between space and economics. Drawing on analyses of geographic economics, industrial economics and the regional sciences, territorial economics offers a theoretical framework which is particularly useful to the theories of development. By exploring why certain territories develop while others do not, territorial economics analyzes the processes of development as endogenous dynamics based on the interaction of several factors. Resources are one of these factors and the major contribution of territorial economics is to explain that it is not only a question of natural or generic resources but also of so-called "specific" resources. It is the "activation" of generic resources by local operators which will transform them into resources "specific" to the territory - in other words resources which cannot be transferred and are not subject to competition. The process of activating a territory's resources presupposes a means of coordinating the different local actors (public and private). The dynamics of development will emerge from the action of the actors who cooperate with a view to optimising the resources of their territory.

\subsection{Sen's theory of capabilities}

The works of SEN were at the origin of the renewal of the indicators used to measure development, in particular the human development indicator (HDI).

Sec's works remain within the framework of neo-classical theory. They do not reduce development to mere economic growth and extend the notion of poverty beyond that of income poverty. Sen believes that development requires construction of individuals' capabilities, a notion which incorporates different aspects such as health, education and freedom of expression (Sen, 1999). The more capabilities an individual possesses, the freer and more capable he is to exercise what Sen calls his "agent" function, i.e. the ability to act and take his destiny in hand. Extending this reasoning, Sen distinguishes between income and economic inequalities, two concepts which do no always overlap. Greater than income inequality, economic inequality covers inequalities in other fields such as education, health, access to work, etc., thereby facilitating the incorporation of particularly 
disadvantaged categories within a single population.

In light of this overview, it is clear that the sources of renewal of the theories of development have contributed to different approaches in analysis of development. Far from focusing exclusively on economic mechanisms, which are nonetheless essential, the theories of development now incorporate other dimensions, including:

- Human capital;

- The actors and their capacity to implement a suitable means of coordination;

- The endogenous nature of development which is reflected both in the mobilisation of actors and the optimisation of local resources;

- The role of institutions; both public and private, formal and informal.

It is these elements of the renewal of the theories of development which give rise to the new paradigms of development.

\section{The paradigms of rural development}

Rural development is defined as follows:

-a local process;

-a process of coordination between actors;

-an endogenous process based on:

-optimisation of local resources (material and nonmaterial),

-mobilisation of all actors, public and private alike,

- Multi-sector development

This approach to rural development refers to four paradigms which belong to the components of the theories of development presented above:

- Governance, concerning the role of the actors and the means of coordination;

- Decentralisation, which concerns the institutions and their operations;

- The new functions of rural areas, which concern the preservation and optimisation of resources; and

-The territory, which concerns the endogenous nature of development and interaction among all other paradigms.

\subsection{Governance}

Institutional efficiency, one of the decisive factors of development, is linked to the means of government adopted.

In common jargon, governance refers to the means of sharing power and the decision-making process in an approach whereby nongovernmental actors play an increasingly important role in the decision-making process (Layll and Tait, 2005). Generally speaking, governance refers to types of partnership and negotiation between actors from different spheres.
In economic terms, the concept of governance designates the mechanism implemented to reduce transaction costs, improve the means of coordination among actors and increase the efficiency of collective action.

It is worth recalling certain criticisms levelled at this notion. The first is that it does not overcome the question of exclusion. Economic and social outcasts have no place as actors in the activity of governance. Furthermore, it demonstrates limitations in the case of "insurmountable" conflicts and depends on the dissemination of information. (Moreau , 2006).

Despite these limitations, governance is, without doubt, an essential paradigm of current approaches to rural development. There is no "model" of rural development that can be generalised and transposed. Rural development is a process of developing and implementing a strategy which is proper to each territory and founded on the optimisation of local material and nonmaterial resources. Thus, it becomes clear that this process can only take place within the framework of governance enabling mobilisation and participation of all public and private actors.

In the light of the long experience in countries such as the United Kingdom and Canada, many lessons can be learned from the works of Anglophone researchers on the subject of rural governance. They note that a changing situation involving the creation of new partnerships within the framework of more or less formalised flexible entities not only fudges the traditional roles of both governmental and nongovernmental bodies, but also favours the emergence of new formal and informal entities (Connelly et al., 2006). In rural areas, certain categories of actors and even certain sectors of activity are "non-visible". This fact undermines the construction of genuine partnerships. On the other hand, governance would appear to be the means of creating the conditions for multi-sector rural development which often proves so difficult to achieve. The cause of this difficulty lies in the sector-based and vertical organisation of the economic activities which gives rise to a situation in which the different economic activities within the same rural territory are juxtaposed and disperesed.

\subsection{Decentralisation}

While governance is a global concept which includes both formal and informal institutions, one of the forms in which it finds a physical manifestation is the process of decentralisation.

The centralised administration system no longer corresponds to the requirements of 
institutional efficiency. It generates increasingly high costs with regard to the search for and processing of information (necessary to decisionmaking) and to negotiations between the parties concerned. It often leads to unsuitable decisionmaking and to local actors becoming less accountable. Defined as the effective transfer of fields of expertise from the central power to the "local governments" (Greffe, 2005), decentralisation involves the transfer of fields of expertise and powers in legal, executive and fiscal matters and of the control over the representatives. This definition nevertheless raises at least two questions: the first is that of the level or degree of decision-making while the second concerns inequalities between the territories. There is no single or universal answer to the first question. It is the relevance and operational specificity which will determine the degree or level of transfer of powers and decision-making procedures. With regard to territorial inequalities, it is true that one of the functions of the central power, in particular through the national budget, is to redistribute financial resources among the territories.

The issue of decentralisation in rural territories differs between countries in the North and those in the South. In the North, decentralisation has led to the strengthening of local governments, the creation of new local entities and a mechanism for establishing contracts between the regions and the central power. An example of this establishment of contracts in France can be seen in the state-region project contract which is a decentralised planning mechanism whereby the state relies on the regions (as local governments) to define and implement territorial planning and development policies.

In the countries of the South, the decentralisation process presupposes the existence of sound and efficient central institutions to facilitate the creation of decentralised entities and perform the transfer of real fields of expertise and powers. In numerous cases, the decentralisation process is undermined by the weakness of the central institutions and their lack of efficiency. Furthermore, particular attention must be paid when creating the legitimacy of the new local entities in rural territories, as there is a risk of that the traditional elites will take over power (Platteau and Abraham, 2001).

Opinion is split on whether decentralisation is a cause or consequence of a local development dynamic, but the two processes are certainly interconnected. It has not been shown whether the implementation of a decentralisation process is, in itself, sufficient to trigger a development process.
However, it is certain that the absence of decentralisation stifles any emerging dynamics.

\subsection{The multi-functionality of rural areas}

Traditionally, the main function of rural areas was to produce agricultural products. Profound demographic transformations within the rural world (cf. point 2) and the ever-present question of the environment have contributed to the emergence of new functions of rural space. This new approach has been made possible by the concept of multi-functionality forged during the 1990s. Rural areas and agriculture do not only produce material goods but also services and nonmaterial goods (Durand and Van huylenbroeck, 2003). Some of these services and nonmaterial goods can be compared to externalities of agricultural production while others are clearly identified as such.

In the countries of the North, these new functions of rural space correspond to a triple demand with regard to quality: the quality of life, the quality of the environment and the quality of agricultural and food products. Rural areas are very much in the spotlight with regard to this new social demand. Agriculture is expected not only to ensure sufficient production, but also to contribute to protecting the environment, managing natural resources and producing healthy and high-quality products. To these expectations can be added the new function of rural areas as a leisure destination as demonstrated by the development of rural tourism in numerous northern countries. ${ }^{3}$

In the countries of the South, while the production function remains just as important as in the past, agriculture and rural areas must contribute to an improved management of rare natural resources subject to considerable pressure. Rural areas also have the task of maintaining a certain demographic and territorial balance by limiting the rural exodus and helping to resolve the economic and social problems observed in the countries of the South, in particular unemployment and poverty.

\subsection{Territory}

The term territory refers to the scope within which the paradigms presented here are implemented and materialised. A physical and more importantly an economic and social area, the territory is the product of the collective action taken by the actors to optimise local resources. It is the framework of the governance, decentralisation and optimisation of all functions.

\footnotetext{
${ }^{3}$ In France, rural tourism has begun to gain ground and represented approximately $35 \%$ of national tourist activity in 2005 .
} 
The actors, institutions and resources are mobilised at territorial level to create a specific and sustainable dynamic. As a forum for a collective development project, the territory becomes the paradigm of rural development through the possibility of illustrating the local, multi-sector and endogenous nature of rural development which thus becomes, more accurately, the development of rural territories.

\section{Conclusion}

Rural development is the development of rural territories; in other words it is a localised process and not a general model applicable to every situation. The new approaches to rural development take account of the demographic and economic transformations observed in rural areas and primarily draw their inspiration from the renewal of the theories of development which took place during the 1990s. By demonstrating the role of efficient institutions in development, the analyses of institutional economics have highlighted governance and decentralisation as paradigms of development. These analyses have also shown how collective action and the coordination of the parties involved represent the cornerstone of the development process. SEN's theory of capabilities, like the theory of endogenous growth, identifies human capital and the operators as decisive factors of development. By identifying "endogenous" innovation as another decisive factor of development, the theory of endogenous growth encourages us to look at local resources as a source of innovation and to emphasise the multi-functionality of rural areas.

Finally, territorial economics enables the local nature of development processes to be materialised and provides a framework of collective action for the optimisation of local resources.

\section{REFERENCES}

Bates R. (1997). economie politique. tome i. Paris: edition presses universitaires de France.

Connelly Y, S., Richardson, T., Miles, T. (2006). situated legitimacy: deliberative arenas and the new rural governance. in journal of rural studies, july 2006.

Coase R. (1988). L'enytreprise, le marché et le droit. Edition Organisation, 2005

Durand G. and van huylenbroeck g. (2003). multifunctionality and rural development: a general framework. in durand, G. and van huylenbroeck G. (editors). multifunctional agriculture: a new paradigm for european agriculture and rural development. edition: ashgate.

Ehrhart C. (2004). la relation entre l'etat et le marche dans le developpement economique: l'experience latino-americaine. in berthomieu, c. et al. (dir.) la restauration du rôle de l'etat dans la croissance et al., développement économique. Paris: editions publisud.

Eurostat news releases on the internet: http://ec.europa.eu/eurostat, May 2010.

Greffe X. (2005). la decentralisation. Paris: edition la decouverte.

Layll C. and Tait J. (2005). shifting policy debates and the implication for governance. in layll and tait (edit.) new modes of governance: developing an integrated policy approach to science, technology, risk and the environment. edition: ashgate, england

Lewis A. (1963). la theorie de la croissance economique. Paris: edition Payot.

Mediterra (2008). the future of agriculture and food in the mediterranean countries. CIHEAM, les presses de sciences po, Paris.

Moreau defarges ph. (2006). la gouvernance. edition Puf.

North D. (1997). the new institutional economics and third world development. in harris, $\mathrm{j}$. and al. (edit.) the new institutional economics and third world development. london and new york: edition routledge.

North D. (2005). le processus de developpement economique. Paris: editions d'organisations.

Platteau jph and abraham A. (2001). imperfections des communautes rurales traditionnelles et developpement participatif. in revue d'economie du developpement, no. 1-2 june, 2001.

EU (2009).Rural development report.http://epc2010.princeton.edu/download.a spx? submissionid $=100983$

Sen A. (1999). un nouveau modele economique: developpement, justice, liberte. Paris: editions odile jacob.

Thorstein C.(1995). l'economie institutionnaliste : les fondateurs. Paris : edition economica.

Toye J. (1997). The new institutional economics and its implications for development theory . In Hariss, J., Hunter, J., Lewis, c. (edit.) The new institutional economics and third world development. London and New york : Edition Routledge.

Willimason, O. (2000). The New institutional Economics,Journal of Economic Literature, Vol. 38. 


\section{المرجعيات الجديدة للتنمية الريفيـة \\ تهاني تحمل كمال عبد الحكيم}

معهد محاصيل منطقة حوض البحر الأبيض المتوسط -3191 - طريق مندى ، 34093 مونبليه - فرنسا

\section{ملخص}

التغير ات العميقة التى شهدتها المناطق الريفية تستدعى اعادة التفكير فى تعريف مفهوم الريف.و يجب لكئ لكى تأخذ العملية

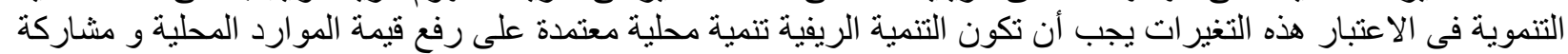

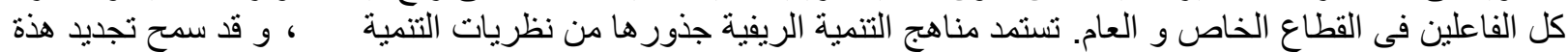

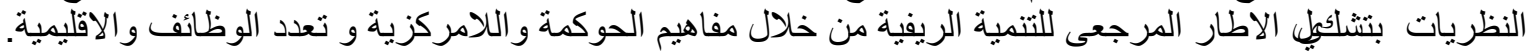

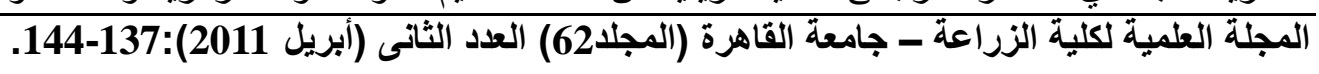

